Original Article

\title{
Effect of Moringa olifera leaves on growth and gut microbiota of Nile tilapia (Oreochromis niloticus)
}

\author{
Efeito das folhas da Moringa olifera no crescimento e na microbiota intestinal da tilápia \\ do Nilo (Oreochromis niloticus)

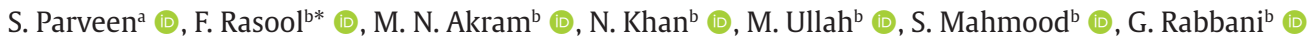 \\ and K. Manzoor ${ }^{\mathrm{b}}$ (1) \\ aUniversity of Agriculture, Faculty of Sciences, Department of Zoology, Wildlife \& Fisheries, Faisalabad, Pakistan \\ bUniversity of Veterinary and Animal Sciences, Faculty of Fisheries \& Wildlife, Department of Fisheries and Aquaculture, Lahore, Pakistan
}

\begin{abstract}
The study was conducted to evaluate the effect of Moringa olifera on the growth and gut health of Tilapia (Oreochromis niloticus). The feed having 30\% crude protein was prepared as an experimental diet with $4 \%, 8 \%$ and $10 \% \mathrm{M}$. olifera leaf supplementation, respectively. The control diet was devoid of $M$. olifera leaves. The 10 weeks feeding trial was carried out on 60 fish in aquaria. Fish was fed @ 3\% of body weight twice a day. Diet with the high level of inclusion of M. olifera leaves significantly increased the growth rate, Survival Rate (SR), Specific Growth Rate (SGR) and Feed Conversion Efficiency (FCE) in all treatment groups compared to the control group. Similarly, Feed Conversion Ratio (FCR) gradually decreased and found highly-significant. To check the gut health of the Tilapia, random samples were selected and dissected. Nutrient agar was used as culture media to check the growth of bacteria. Pour Plate Method was used for viable colonies count by colony counter. Through staining method, the different bacteria such as Escherichia coli, Salmonella, Shigella and Pseudomonas aeruginosa were identify abundantly in the intestine of control diet fish but less number present in treatment diets groups. These results showed that $M$. olifera leaves up to $10 \%$ of dietary protein can be used for Nile tilapia for significant growth and healthy gut microbiota of fish.
\end{abstract}

Keywords: body weight gain, FCE, FCR, Moringa olifera leaves, Gram staining, survival rate.

\begin{abstract}
Resumo
O estudo foi conduzido para avaliar o efeito da Moringa olifera no crescimento e saúde intestinal da tilápia (Oreochromis niloticus). A ração com $30 \%$ de proteína bruta foi preparada como dieta experimental com $4 \%, 8 \%$ e $10 \%$ de suplementação de folhas de M. olifera, respectivamente. A dieta controle foi desprovida de folhas de M. olifera. $O$ ensaio de alimentação de 10 semanas foi realizado em 60 peixes em aquários. 0 peixe pesava $3 \%$ do peso corporal duas vezes ao dia. A dieta com alto nível de inclusão de folhas de $M$. olifera aumentou significativamente a taxa de crescimento, taxa de sobrevivência (SR), taxa de crescimento de sobrevivência (SGR) e eficiência de conversão alimentar (FCE) em todos os grupos de tratamento em comparação com o grupo de controle. Da mesma forma, a taxa de conversão de alimentação (FCR) diminuiu gradualmente e foi considerada altamente significativa. Para verificar a saúde intestinal da tilápia, amostras aleatórias foram selecionadas e dissecadas. O ágar nutriente foi usado como meio de cultura para verificar o crescimento das bactérias. O método da placa de Verter foi usado para a contagem de colônias viáveis por contador de colônias. Através do método de coloração, diferentes como Escherichia coli, Salmonella, Shigella e Pseudomonas aeruginosa foram identificados abundantemente no intestino de peixes da dieta controle, mas em menor número nos grupos de dieta de tratamento. Esses resultados mostraram que $M$. olifera deixa até $10 \%$ da proteína dietética e pode ser usado para tilápia do Nilo para um crescimento significativo e microbiota intestinal saudável de peixes.
\end{abstract}

Palavras-chave: ganho de peso corporal, FCE, FCR, folhas de Moringa olifera, coloração de Gram, taxa de sobrevivência.

\section{Introduction}

Global fast-growing sector aquaculture recorded 114.5 million tonnes in wet weight and aquatic farmed raised fauna grew on 5.3\%/year in 2001-2018 (FAO, 2020). To increase significant fish feed production to attain high fish growth (Francis et al., 2001). In last few decades the use of fishmeal in fish feed formulations due to their high profile of protein can no interminable because of overfishing, fluctuating quality and pricey (Tacon et al., 2011; Ag, 2014). Nutritionists, aqua culturist, researcher and feed industries have organized different researches and polite projects to 
bring down the use of fishmeal (Tacon and Metian, 2013; Rana et al., 2009). To improve quality and cost effect of fish feed; substitution of fishmeal with topically cheaper plant ingredients (Tacon et al., 2006). Plant can be used as a protein source for fish feed. Conventional and considerable plant sources are soybean, groundnut, cotton seed and rapeseed meal (Jackson et al., 1982; El Sayed, 1990). However, livestock, human consumption and industrial use of these sources make them costly and put far away from the reach of fish farmers, researchers and producers of aqua feed (Fasakin et al., 1999). Therefore, for research purposes such more economical and environment-friendly protein sources are used that are obtained from the plant's leaves, seeds and other agriculture by-products (El Sayed, 1990; Siddhuraju and Becker, 2001). Animals and humans use plant products as a valuable source to maintain their health. Plants have a large number of chemical substances that contain medicinal and curative agents.

Moringa oleifera belongs to family Moringaceae is native to tropical and sub-tropical regions of Pakistan, India, Africa, and Arabia, the western sub-Himalayan region and Asia Minor (Mughal et al., 1999). M. oleifera is cultivated as vegetable (leaves, pods flowers, roasted and seed) spice mainly present in roots and have medicinal uses (Rebecca et al., 2006). These parts are used as antipyretic, antiepileptic and antihypertensive (Dahot, 1988), antiinflammatory (Mehta et al., 2003) anti- ulcerative (Mahajan and Mehta, 2007) anti-diabetics, anti-bacterial, anti-fungal and anti-oxidant. Moreover, $M$. oleifera is fast growing and have the power to purify water. (Nikkon, 2003).

Tilapia is worldwide preferable aquaculture fish species due to rapidly growing ability, falling to family Cichlidae, has laterally compressed, deep bodies, like other cichlids. Their lower pharyngeal bones are fused into a single toothbearing structure. Beside their temperature sensitivity, Tilapia can exist and adapt wide range of conditions. Tilapia survival has been testified in brackish and mostly, enough salty water cause mortality in fresh water fish (Chapman, 2000; Lind et al., 2019). The aims of the present study were to evaluate the suitability of $M$. oleifera leaves as a partial protein replacement for fish in practical diets of Nile tilapia, based on its effects on growth performance and total bacterial count (positive or negative) on different culture media such as tryptone soya agar (TSA), Nutrient agar (NA) and Eosin methylene blue (EMB).

\section{Materials and Methods}

\subsection{Experimental design}

The present study was conducted at the hatchery, Department of Fisheries and Aquaculture, the University of Veterinary and Animal Sciences, Ravi Campus, Pattoki. The experiment was conducted in glass aquariums and the experimental fish species was tilapia (Oreochromis niloticus). Sixty (60) Tilapia fish, of 10 grams were collected from the pond and were placed in four different glass aquaria. Each aquarium contained 15 fish and categorized in three different treatments and one control group. The Control group was fed on a normal diet, devoid of M. oleifera leaves. Whereas Treatment 1 was (4\%), Treatment 2 (8\%) and Treatment $3(10 \%)$ M. oleifera leaves supplementation. Water quality parameters; dissolved Oxygen and $\mathrm{pH}$ were monitored during the whole trial respectively.

\subsection{Feed formulation}

A feed with $30 \% \mathrm{CP}$ was prepared by $4 \%, 8 \%$ and $10 \%$ M. oleifera leaves supplementation with different feed ingredients as shown in Table 1. The control diet was free from M. oleifera leaves. Fish were fed $3 \%$ of body weight twice a day during the entire trial. Feed formulation is below in Table 1.

\subsection{Evaluation of growth parameters}

Growth performance and diet nutrients consumption were evaluated in terms of body weight gain (BWG), length gain, daily body weight gain (DWG), feed conversion ratio (FCR), survival rate (SR) and specific growth rate (SGR).

\subsection{Weight gain $\%$}

The increased body weight was figured as difference between final and initial weight by using the Formula 1:

Weight gain $=$ Final body weight $(g)-$ Initial body weight $(g)$

\subsection{Feed Conversion Ratio (FCR)}

Ratio of feed intake to weight gain was evaluated by the following Formula 2: (Shabir et al.,2003).

$$
F C R=\text { Feed intake }(g) / \text { Wet weight gain }(g)
$$

Table 1. Ingredient of fish feed with $30 \%$ crude protein (C.P).

\begin{tabular}{ccccc}
\hline Ingredients & Control & Treatment 1 & Treatment 2 & Treatment 3 \\
\hline Fish meal & 25 & 20 & 20 & 20 \\
Soya bean meal & 16 & 16 & 14 & 13 \\
Maize gluten & 15 & 16 & 40 & 13 \\
Rice polish & 40 & 40 & 3 & 40 \\
Molasses & 3 & 3 & 1 & 3 \\
Vitamin & 1 & 1 & 08 & 1 \\
Moringa olifera leaves & 0 & 04 & 10 \\
\hline
\end{tabular}

Above feed, ingredients were used in fish feed as upper described concentrations. All treatment groups feed was inoculated with $4 \%, 8 \%$ and $10 \%$ Moringa olifera leaves. While, control diet was free from Moringa olifera leaves. 


\subsection{Specific Growth Rate (SGR)}

Specific growth rate was measured by using the Formula 3:

$S G R \% /$ day $=\ln (W 1)-\ln (W 2) \times 100 /$ Number of days

\subsection{Daily feed intake}

Daily feed intake was calculated with following Formula 4 as previously described by (Helland et al., 1996)

Air - dry feed eaten $(g)=\left(A X A_{D M} / 100\right)-\left(W \times W_{D M} / R\right) A D, / 100(4)$

A denoted weight of air-dry feed $(\mathrm{g}), \mathrm{A}_{\mathrm{DM}}$ for dry matter content of air-dry feed (\%), $\mathrm{W}$ is weight of waste feed collected $(\mathrm{g}), \mathrm{W}_{\mathrm{DM}}$ for dry matter content of waste feed (\%), and R for recovery of dry matter of waste feed (\%)

\subsection{Bacterial isolation}

Three randomly chosen fish from each treatment were dissected and the intestine was removed from each sample with sterile dissecting instruments. The intestine was longitudinally opened and gently agitated for 2-3 minutes in a 9\% saline solution in a flask to remove the other contents. Eppendorf tubes were filled with 900 $\mu$ l, 9\% normal saline solution (sterilized). $100 \mu \mathrm{l}$ solution containing intestinal content was transferred to $900 \mu \mathrm{l}$ normal saline solutions in Eppendorf tubes. This acted as $1^{\text {st }}$ dilution, then $100 \mu \mathrm{l}$ solutions from that dilution was added into $900 \mu \mathrm{l}$ in the next tube. This resulted 100 times second dilution. Bacterial colonies were cultured by pouring and spreading $10 \mu \mathrm{l}$ the solution in petri plate contained $20 \mathrm{ml}$ media and were placed in an incubator at $37^{\circ} \mathrm{C}$ for 24 to 48 hours. Colonies of bacteria were counted after incubation of 24 and 48 hours (Canberra, 1999).

\subsection{Total viable count}

The pour plate method was used for the estimation of viable counts. $15-20 \mathrm{ml}$ sterilized Tryptic soy agar was melted and then cooled at $45{ }^{\circ} \mathrm{C}$ was settled for solidification. Nutrient agar and Eosin methylene blue
(EMB) were employed for the microbial count (Buchanan and Gibbons, 1974) (Formula 5).

Total Viable Count $=$ Average no. of colonies $\times$ Dilution factor

\subsection{Statistical analysis}

Data of growth parameters were put through one-way analysis of variance (ANOVA) (Steel et al., 1996). Means difference were evaluated by Tukey's Honestly Significant Difference Test and considered significant at $\mathrm{P}<0.05$ (Snedecor and Cochran, 1991).

\section{Results}

\subsection{Growth parameter}

Growth performance and feed utilization of Tilapia is given in Table 2. Growth performance of Tilapia revealed the body weight, body length, body weight gain and daily body weight gain were significantly $(\mathrm{P}<0.05)$ increased in treatments T1, T2 and T3. Body weight was higher in the T3 group as compared to T2, T1, and Control group respectively. A similar pattern was observed for body length, body weight gain and daily body weight gain. In term of feed utilization, the results showed non-significant difference found in FCR, FCE, SGR, FI, SR, FCR and value of mean range cameto1.96 to 2.85. The lowest FCR with high level inclusion of M. oleifera leaves was observed in T3. FI increased in all groups while FCR were decreased. SGR was increased in the all-treatments groups. All fish grow normally but a high mortality rate was found in the control group although no mortality observed in T3. Progressively increased the level of $M$. oleifera leaves in the diet significantly shown the significant growth and survival rate of Tilapia and indicated the positive effect of M. oleifera leaves on the fish health. Similarly, Figure 1 shows the overall growth performance of the fish after using different treatments. The bar chart clearly showed the maximum weight gain and length gain in treatment 2 and treatment 3 . Whereas,

Table 2. Statistical analysis of growth performance parameters and feed utilization abilities of Tilapia.

\begin{tabular}{cccccc}
\hline Parameters & Control & Treatment 1 & Treatment 2 & Treatment 3 & P value \\
\hline Body weight & $25.55 \pm 15.36 \mathrm{a}$ & $27.80 \pm 16.63 \mathrm{bcd}$ & $38.33 \pm 26.39 \mathrm{cbd}$ & $45.21 \pm 30.16 \mathrm{dbc}$ & $0.000^{*}$ \\
Body length & $12.45 \pm 7.54 \mathrm{acd}$ & $13.40 \pm 7.90 \mathrm{bcd}$ & $17.04 \pm 11.94 \mathrm{cab}$ & $16.2 \pm 9.29 \mathrm{dab}$ & $0.003^{*}$ \\
Body weight gain & $15.43 \pm 16.80 \mathrm{acd}$ & $17.23 \pm 17.07 \mathrm{bcd}$ & $38.33 \pm 26.39 \mathrm{cab}$ & $45.21 \pm 30.16 \mathrm{dab}$ & $0.000^{*}$ \\
Body length gain & $12.45 \pm 7.54 \mathrm{acd}$ & $13.40 \pm 7.90 \mathrm{bcd}$ & $17.04 \pm 11.94 \mathrm{cab}$ & $16.2 \pm 9.29 \mathrm{dab}$ & $0.000^{*}$ \\
D.W.G. & $1.02 \pm 1.12 \mathrm{acd}$ & $1.14 \pm 1.13 \mathrm{bcd}$ & $1.67 \pm 1.65 \mathrm{cab}$ & $1.96 \pm 1.95 \mathrm{dab}$ & $0.003^{*}$ \\
F. I. & $331.25 \pm 258.13 \mathrm{a}$ & $226.62 \pm 135.50 \mathrm{~b}$ & $384.72 \pm 123.84 \mathrm{c}$ & $376.14 \pm 256.72 \mathrm{~d}$ & 0.628 \\
F.C.R. & $2.85 \pm 1.34 \mathrm{abd}$ & $1.47 \pm 0.63 \mathrm{ba}$ & $1.75 \pm 0.12 \mathrm{c}$ & $1.52 \pm 0.06 \mathrm{da}$ & 0.080 \\
F.C.E. & $0.40 \pm 0.14 \mathrm{ab}$ & $0.80 \pm 0.42 \mathrm{ba}$ & $0.57 \pm 0.50 \mathrm{c}$ & $0.70 \pm 0.14 \mathrm{~d}$ & 0.149 \\
S.G.R. & $0.97 \pm 0.65 \mathrm{a}$ & $0.12 \pm 1.00 \mathrm{~b}$ & $1.42 \pm 1.15 \mathrm{c}$ & $1.59 \pm 1.30 \mathrm{~d}$ & 0.848 \\
S.R. & $88.00 \pm 14.30 \mathrm{acd}$ & $95.80 \pm 3.83 \mathrm{~b}$ & $98.00 \pm 3.13 \mathrm{ca}$ & $100.00 \pm 0.00 \mathrm{da}$ & 0.096 \\
\hline
\end{tabular}

D.W.G. = Daily Body weight Gain; F.I. = Feed intake; F.C.R. = Feed conversion ratio; F.C.E. = Feed conversion efficiency; S.G.R. = Survival Growth Rate; S.R. = Survival Rate. * Shows significant results among treatments at $5 \%$ significance level. ${ }^{\mathrm{a}, \mathrm{b}}$ the mean values with different case letters shows significantly different from each other (DMRT). 
weight gain and length gain in control and treatment 1 can be seen as identical. The graph shows that the SR of fish in Treatment 3 remains approximately a hundred percent while others were less.

\subsection{Bacterial growth}

Microbiota in the intestine of sampled fish from each treatment were examined and compared with the control group. The microbiota of the control group was different from treatments. There were present maximum numbers of disease-causing bacteria in the intestine of the control group compared to the treatments.

In the present study Escherichia coli, Pseudomonas aeruginosa, Shigella and Salmonellae were identified in large amounts in the control group as compared to the treatments that contain a different concentration of $M$. oleifera leaves. There was $80 \%$ growth of bacteria in the control group that is devoid of $M$. oleifera leaves and resistant to control group but in the treatments that contain M. oleifera there were minimum no of bacteria because M. oleifera inhibit the growth of bacteria listed in Table 3.

\section{Growth Perfomance Parameters}

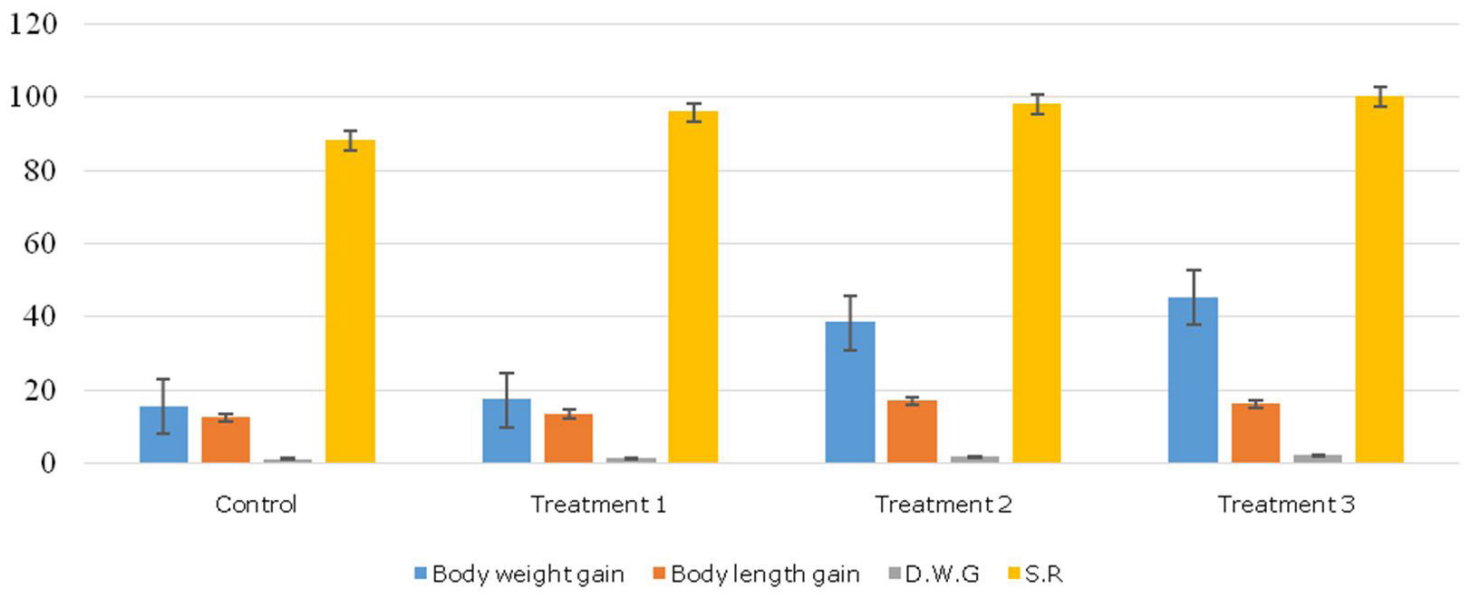

Figure 1. Growth performance parameters.

Table 3. Bacterial susceptibility in experimental fish at concentration of $20 \mathrm{~mL} / 100 \mu \mathrm{l}$.

\begin{tabular}{|c|c|c|c|c|}
\hline & Escherichia coli & $\begin{array}{c}\text { Pseudomonas } \\
\text { aeruginosa }\end{array}$ & Shigelae & Salmonella \\
\hline \multirow[t]{5}{*}{ Control } & 1010 & 5000 & 1098 & 4000 \\
\hline & 789 & 1090 & 1000 & 3598 \\
\hline & 554 & 567 & 967 & 769 \\
\hline & 551 & 430 & 890 & 679 \\
\hline & 432 & 234 & 760 & 560 \\
\hline \multirow[t]{5}{*}{ Treatment 1} & 21 & 09 & 657 & 67 \\
\hline & 54 & 05 & 651 & 51 \\
\hline & 51 & 03 & 545 & 21 \\
\hline & 41 & 00 & 530 & 10 \\
\hline & 01 & 00 & 521 & 00 \\
\hline \multirow[t]{5}{*}{ Treatment 2} & 16 & 10 & 78 & 45 \\
\hline & 12 & 00 & 67 & 43 \\
\hline & 05 & 00 & 43 & 20 \\
\hline & 00 & 00 & 21 & 21 \\
\hline & 00 & 00 & 09 & 10 \\
\hline \multirow[t]{5}{*}{ Treatment 3} & 08 & 08 & 00 & 08 \\
\hline & 02 & 05 & 00 & 05 \\
\hline & 00 & 03 & 00 & 02 \\
\hline & 00 & 00 & 00 & 02 \\
\hline & 00 & 00 & 00 & 00 \\
\hline
\end{tabular}




\section{Discussions}

Earlier studies evaluated significantly the effect of Moringa olifera (M. oleifera) on growth parameters (Ozovehe, 2013; Ahmed et al., 2014). Those significant results recognized that Moringa is most effective source of protein, crude fibers, and fats (Francis et al., 2001). Recent study conducted in Egypt revealed that Moringa leaf meal improves the growth rate of Nile tilapia (Elabd et al., 2019). Puycha et al. (2017) concluded that M. oleifera leaf @ $100 \mathrm{~g} / \mathrm{kg}$ demonstrate significant growth. Another study reported the significant growth rate of tilapia fed with M. oleifera supplements (Tiimub et al., 2020). Protein extracted from $M$. oleifera seed at $400 \mathrm{mg} \mathrm{kg}^{-1}$ used as growth promoter in Tilapia (Stadtlander et al., 2013). Aqueous extract of $M$. oleifera is used as growth accentuate for Tilapia (Shourbela et al., 2020)

In a previous study $M$. olifera examined as a better antibacterial effect against Gram-positive bacteria ( $S$. aureus and E. faecalis) than Gram-negative strains (E. coli, Salmonella, P. aeruginosa, V. parahaemolyticus and A. caviae) (Peixoto et al., 2011). Moringa seed contains pterygospermin, moringine, 4-( $\alpha$-L-rhamnosyloxy)-phenylacetonitrile glycosides and 4-( $\alpha$-L-rhamnosyloxy) benzylisothiocyanate and constituents inhibit the growth of Streptococcus, E. coli, Shigella and Pseudomonas aeruginosa (Jeon et al., 2014). Another study was conducted on Moringa seed extract to observed the Salmonella enteritidis cultures to be vulnerable to water that is treated by Moringa seed extract and results showed that the extract is not able to inhibit the growth of salmonella (Madsen et al., 1987). In 2010 study held by Oluduro et al. (2010), use M. oleifera, seeds showed strong antibacterial activity against Pseudomonas aeruginosa, E. coli, S. aureus, Penicillium sclerotigenum and Cladosporium cladosporioides. At Sao Paulo study was held by Viera et al. (2010), evaluated the effect of M. oleifera against Gram Positive and Gram-negative bacteria. All the previous studies showed a close resemblance with the present study.

\section{Conclusion}

In conclusion, the results obtained from the present study recommended Moringa oleifara leaves could replace with or used with fish meal in Nile tilapia (O. niloticus) feed as a growth enhancer. It is suggested that $M$. olifera leaves added in cultured fish diet had the best growth performance parameters with minimum cost and maximize profit. $M$. olifera leaves inhibit the growth of various disease-causing bacteria such as E. coli, P. aeruginosa, Shigella and Salmonella in the intestine of fish. The presence of minerals and vitamins in M. olifera leaves help to enhance the immune system and cure a myriad of diseases. The antimicrobial factors found to present in $M$. olifera leaves is responsible for antimicrobial properties.

\section{References}

AG, M.N., 2014. Replacing fishmeal with kikuyu grass and Moringa leaves: effects on growth, protein digestibility, histological and haematological parameters in Clarias gariepinus. Turkish Journal of Fisheries and Aquatic Sciences, vol. 14, no. 3, pp. 795-806.

AHMED, H. S., ADEL, M., and ADEL, E., 2014. Incorporation of Moringa oleifera leaf in Nile tilapia (Oreochromis niloticus) diet and its effect on growth performance and immune status. Journal of Veterinary Science, vol. 1, no. 1, pp. 8.6-8.14.

BUCHANAN, R.E. and GIBBONS, N.E., 1974. Bergey's manual of determinative racteriology. 8th ed. Battimore: Williams and Wilkins Company. https://doi.org/10.1111/j.1550-7408.1975. tb00935.x.

CANBERRA, 1999. National translocation policy for the translocation of live aquatic organismsissues principles and guidelines for implementation. Canberra: Ministerial Council on Forestry Fisheries and Aquaculture, pp. 31.

CHAPMAN, F.A., 2000. Culture of hybrid tilapia: a reference profile. Gainesville: University of Florida Cooperative Extension Service, Institute of Food and Agriculture Sciences, EDIS.

DAHOT, M.U., 1988. Vitamin contents of the flowers and seeds of Moringa oleifera. Pakistan Journal of Biochemistry, vol. 21, pp. 21-24.

ELABD, H., SOROR, E., EL-ASELY, A., EL-GAWAD, E.A. and ABBASS, A., 2019. Dietary supplementation of Moringa leaf meal for Nile tilapia Oreochromis niloticus: effect on growth and stress indices. The Egyptian Journal of Aquatic Research, vol. 45, no. 3, pp. 265-271. http://dx.doi.org/10.1016/j.ejar.2019.05.009.

EL-SAYED, A.F.M., 1990. Long-term evaluation of cotton seed meal as a protein source for Nile tilapia, Oreochromis niloticus (Linn.). Aquaculture, vol. 84, no. 3-4, pp. 315-320. http://dx.doi. org/10.1016/0044-8486(90)90096-6.

FASAKIN, E.A., BALOGUN, A.M. and FASURU, B.E., 1999. Use of duckweed, Spirodela polyrrhiza L. Schleiden, as a protein feedstuff in practical diets for tilapia, Oreochromis niloticus $L$. Aquaculture Research, vol. 30, no. 5, pp. 313-318. http://dx.doi. org/10.1046/j.1365-2109.1999.00318.x.

FOOD AND AGRICULTURE ORGANIZATION OF THE UNITED NATIONS - FAO, 2020. The state of world fisheries and aquaculture 2020: sustainability in action. Rome: FAO.

FRANCIS, G., MAKKAR, H.P. and BECKER, K., 2001. Antinutritional factors present in plant-derived alternate fish feed ingredients and their effects in fish. Aquaculture, vol. 199, no. 3-4, pp. 197-227. http://dx.doi.org/10.1016/S0044-8486(01)00526-9.

HELLAND, S.J., GRISDALE-HELLAND, B. and NERLAND, S., 1996. A simple method for the measurement of daily feed intake of groups of fish in tanks. Aquaculture, vol. 139, no. 1-2, pp. 157-163. http://dx.doi.org/10.1016/0044-8486(95)01145-5.

JACKSON, A.J., CAPPER, B.S. and MATTY, A.J., 1982. Evaluation of some plant proteins in complete diets for the tilapia Sarotherodon mossambicus. Aquaculture, vol. 27, no. 2, pp. 97-109. http:// dx.doi.org/10.1016/0044-8486(82)90129-6.

JEON, S.R., LEE, K.H., SHIN, D.H., KWON, S.S. and HWANG, J.S., 2014. Synergistic antimicrobial efficacy of mesoporous $\mathrm{Zn}$ loaded with 4-( $\alpha$-L-rhamnosyloxy)-benzyl isothiocyanate isolated from the Moringa oleifera seed. The Journal of General and Applied Microbiology, vol. 60, no. 6, pp. 251-255. http://dx.doi. org/10.2323/jgam.60.251. PMid:25742976.

LIND, C.E., AGYAKWAH, S.K., ATTIPOE, F.Y., NUGENT, C., CROOIJMANS, R.P. and TOGUYENI, A., 2019. Genetic diversity of Nile tilapia (Oreochromis niloticus) throughout West Africa. Scientific Reports, vol. 9, no. 1, pp. 16767. http://dx.doi.org/10.1038/s41598-01953295-y. PMid:31727970.

MADSEN, M., SCHLUNDT, J. and OMER, E.F., 1987. Effect of water coagulation by seeds of Moringa oleifera on systemic and local anaphylaxis. The Journal of Tropical Medicine and Hygiene, 
vol. 90, no. 3, pp. 101-109. http://dx.doi.org/10.1016/03788741(88)90285-1. PMid:3586089.

MAHAJAN, S.G. and MEHTA, A.A., 2007. Inhibitory action of ethanolic extract of seeds of Moringa oleifera Lam. on systemic and local anaphylaxis. Journal of Immunotoxicology, vol. 4, no. 4, pp. 287-294. http://dx.doi.org/10.1080/15476910701680137. PMid:18958739.

MEHTA, K., BALARAMAN, R., AMIN, A.H., BAFNA, P.A. and GULATI, O.D., 2003. Effect of fruits of Moringa oleifera on the lipid profile of normal and hypercholesterolaemic rabbits. Journal of Ethnopharmacology, vol. 86, no. 2-3, pp. 191-195. http:// dx.doi.org/10.1016/S0378-8741(03)00075-8. PMid:12738086.

MUGHAL, M.H., ALI, G., SRIVASTAVA, P.S. and IQBAL, M., 1999. Improvement of drumstick (Moringa pterygosperma Gaertn) a unique source of food and medicine through tissue culture. Hamdard Medicus, vol. 42, no. 1, pp. 37-42.

NIKKON, F., 2003. In vitro antimicrobial activity of the compound isolated from chloroform extract of Moringa oleifera Lam. Pakistan Journal of Biological Sciences, vol. 6, no. 22, pp. 1888-1890. http:// dx.doi.org/10.3923/pjbs.2003.1888.1890.

OLUDURO, O.A., ADERIYE, B.I., CONNOLLY, J.D., AKINTAYO, E.T. and FAMUREWA, O., 2010. Characterization and antimicrobial activity of 4-( $\beta$-D-glucopyranosyl- $1 \rightarrow 4-\alpha$-L-rhamnopyranosyloxy)benzyl thiocarboxamide; a novel bioactive compound from Moringa oleifera seed extract. Folia Microbiologica, vol. 55, no. 5, pp. 422-426. http://dx.doi.org/10.1007/s12223-010-0071-0. PMid:20941575.

OZOVEHE, B.N., 2013. Growth performance, haematological indices and some biochemical enzymes of juveniles Clarias gariepinus (Burchell 1822) fed varying levels of Moringa oleifera leaf meal diet. Journal of Aquaculture Research \& Development, vol. 4, no. 2. http://dx.doi.org/10.4172/2155-9546.1000166.

PEIXOTO, J.R.O., SILVA, G.C., COSTA, R.A., VIEIRA, G.H.F., FONTENELLE FILHO, A.A. and DOS FERNANDES VIEIRA, R.H.S., 2011. In vitro antibacterial effect of aqueous and ethanolic Moringa leaf extracts. Asian Pacific Journal of Tropical Medicine, vol. 4, no. 3, pp. 201-204. http://dx.doi.org/10.1016/S1995-7645(11)600692. PMid:21771453.

PUYCHA, K., YUANGSOI, B., CHAROENWATTANASAK, S., WONGMANEEPRATEEP, S., NIAMPHITHAK, P. and WIRIYAPATTANASUB, P., 2017. Effect of moringa (Moringa oleifera) leaf supplementation on growth performance and feed utilization of Bocourti's catfish (Pangasius bocourti). Agriculture and Natural Resources, vol.51, no. 4, pp. 286-291. http://dx.doi. org/10.1016/j.anres.2017.10.001.

RANA, K.J., SIRIWARDENA, S. and HASAN, M.R., 2009. Impact of rising feed ingredient prices on aquafeeds and aquaculture production. Rome: Food and Agriculture Organization of the United Nations. no. 541.

REBECCA, H.S.U., SHARON, M., ARBAINSYAH, A. and LUCIENNE, D., 2006. Moringa oleifera: medicinal and socio-economic uses. Leiden: International Course on Economic Botany, pp. 2-6.
SHABIR, S., SALIM, M. and RASHID, M., 2003 [viewed 10 April 2021]. Study on the feed conversion ratio (FCR) in major carp Cirrhinus mrigala fed on sunflower meal, wheat bran and maize gluten. Pakistan Veterinary Journal [online], vol. 23, no. 1, pp. 1-3. Available from: http://pvj.com.pk/abstract/23_1/1.htm

SHOURBELA, R.M., EL-HAWARRY, W.N., AM, A.E.L. and ABO-KORA, S.Y., 2020. Potentiality of Moringa oleifera aqueous extract as a growth modulator and antistress in acute hypoxic Nile tilapia Oreochromis niloticus. Iranian Journal of Fisheries Science, vol. 19, no. 1, pp. 67-84.

SIDDHURAJU, P. and BECKER, K., 2001. Effect of various domestic processing methods on antinutrients and in vitro protein and starch digestibility of two indigenous varieties of Indian tribal pulse, Mucuna pruriens var. utilis. Journal of Agricultural and Food Chemistry, vol. 49, no. 6, pp. 3058-3067. http://dx.doi. org/10.1021/jf001453q. PMid:11410009.

SNEDECOR, G.W. and COCHRAN, W.G., 1991. Statistical methods. 8th ed. Iowa: Iowa State University Press, pp. 503.

STADTLANDER, T., SANDER, C., KUMAR, V., MAKKAR, H. and BECKER, K., 2013. Effects of Moringa oleifera Lam. dietary seed protein extracts on growth, nutrient utilization and blood parameters in common carp (Cyprinus carpio) and Nile tilapia (Oreochromis niloticus, L.). Planta Medica, vol. 79, no. 13, pp. 21. http://dx.doi. org/10.1055/s-0033-1352329.

STEEL, R.G.D., TORRIE, J.H. and DICKEY, D.A., 1996. Principles and procedures of statistics. 3rd ed. New York: McGraw Hill International Book Company, pp. 336-352.

TACON, A.G. and METIAN, M., 2013. Fish matters: importance of aquatic foods in human nutrition and global food supply. Reviews in Fisheries Science, vol. 21, no. 1, pp. 22-38. http:// dx.doi.org/10.1080/10641262.2012.753405.

TACON, A.G., HASAN, M.R. and METIAN, M., 2011. Demand and supply of feed ingredients for farmed fish and crustaceans: trends and prospects. Rome: Food and Agriculture Organization of the United Nations. FAO Fisheries and Aquaculture Technical Paper, no. 564.

TACON, A.G., HASAN, M.R., SUBASINGHE, R.P., 2006. Use of fishery resources as feed inputs to aquaculture development: trends and policy implications. Rome: Food and Agriculture Organization of the United Nations. no. 1018. https://doi.org/10.1093/ law:epil/9780199231690/e462.

TIIMUB, B.M., MPANGA, I.K., TIIMOB, G.L., TIIMOB, R.W., BAANI, I. and LAATMAN TIIMOB, E., 2020. Effect of Moringa oleifera feed supplements on all-male tilapia growth performance at TanoDumasi Pilot Aquaculture Centre. EAS Journal of Biotechnology Genetics, vol. 2, no. 5, pp. 67-83. http://dx.doi.org/10.36349/ easjbg.2020.v02i05.001.

VIERA, G.H.F., MOURÃO, J.A., ÂNGELO, Â.M., COSTA, R.A. and VIEIRA, R.H.S.D.F., 2010. Antibacterial effect (in vitro) of Moringa oleifera and Annona muricata against Gram positive and Gram-negative bacteria. Revista do Instituto de Medicina Tropical de São Paulo, vol. 52, no. 3, pp. 129-132. http://dx.doi.org/10.1590/S003646652010000300003. PMid:20602021. 